\title{
Business plan for a Zen garden
}

\author{
Maja ŽIBRAT, Karmen PAŽEK, Vesna WEINGERL ${ }^{*}$ \\ University of Maribor, Faculty of Agriculture and Life sciences, \\ Pivola 10, SI-2311 Hoče, Slovenia
}

\begin{abstract}
The placement of a theme park in the form of a Zen garden, as a business opportunity in the Slovenian rural area, is discussed. The design of the garden, with all the major points of a standard business plan, is accurately presented, with a description of the business, branch, and services, market analysis, marketing strategy, financial projections, and a plan of the work and activities. The financial aspect is presented as the amount of investment, net present value, and internal rate of return. The amount of investment is estimated at $€ 14.891$, which should be reimbursed within 4 years of operations. The estimated internal rate of return is estimated at $16.86 \%$. Part of the study is the market analysis - conduction of a survey into knowledge of, and interest in, Zen and Zen gardens. The principles of landscape ecology are respected, as the Zen garden would be set in the woods and will blend seamlessly into the landscape.
\end{abstract}

Key words: theme parks, sustainable tourism, investment, financial indicators, landscape ecology

\section{INTRODUCTION}

The Government of the Republic of Slovenia defines tourism as one of the most important economic and strategic sectors, as it creates new jobs and has a highly positive impact on balanced regional development. From the Slovenian Tourism Development Strategy (2012-2016), which is the basic document for planning of tourism development at the national level, we can see that the designers of Slovenian tourism have, in recent years, reached a consensus that all tourism development must become sustainable (Ministry of Economic Development and Technology 2012).

Sustainable tourism development does not deplete natural resources, and does not pollute the environment, while respecting culture and human and ethical values. We can talk about soft tourism, which is the most suitable for rural areas. At the same time, sustainable development focuses not only on environmental issues, but emphasises development that meets the needs of the present without compromising the ability of future generations. Sustainable development links the concern for the capacity of natural systems with the social challenges facing humanity. Tourism is one of the fundamental pillars of balanced economic, social, ethical, and environmental development - these are the components that comprise sustainable development. Thus, tourism is becoming an extremely important sector of both the global and the local economy. The sector is expected to grow constantly, both in qualitative and quantitative terms.

Any development of tourism cannot happen without affecting the development of the entire region. When we attract tourists with one attraction, they will visit by the way also other attractions, they will use public transport, eat in local restaurants and sleep in nearby hotels, which brings benefit to all actors and hence the entire region. However, there may cause also negative effects, such as increased traffic and thus greater noise and air pollution.

Nowadays, "relaxed tourism" is booming as people are in a constant hurry and are under stress, so there is a growing demand for relaxation techniques and a need for places where they can find peace. In the north-east of Slovenia alone, there are 7 thermal spas, over 25 tourist farms, and many other activities which attract tourists who want on-site facilities.

The landscape is a functional set of ecosystems and their environment, which is namely open, but able to be to a certain extent self-regulating. Landscape ecology is the study of the composition, structure and function of landscapes. A 
landscape is not necessarily defined by its size; rather, it is defined by an interacting mosaic of elements (e.g. ecosystems) relevant to some phenomenon under consideration (at any scale). Thus, a landscape is simply an area of land (at any scale) containing an interesting pattern that affects and is affected by an ecological process of interest (Turner et al. 2001, Turner, 2005).

Zen is the way of thinking, striving for inner peace and acceptance of other people and things as they are. To live in the present, disregarding the past and do not worry about the future. During the development of the Zen, various teachers used their own methods and approaches and that's why Zen parts for Japanese and Chinese. In addition, Zen parts of the course also due to the geographical division of the two countries. The Buddhist concept is completely enclosed in a Zen only that this concept arose the legend of Siddhartha Gautama, nowadays known as Gautama Buddha. The great masters of Zen and Buddhism may precisely explain the similarities and differences. However, if you live according to the principles of Zen, you live also according to the principles of Buddhism and vice versa. The Japanese and the Chinese, who were the originators of Zen thinking, created special gardens, called Zen gardens, which use many natural materials, such as sand, stone, rocks, and bamboo. Simple lines are used that do not impose any form, so each visitor experiences the garden in his own way. Zen garden it can be used as a tool to facilitate the achievement of the Zen, or just for a walk, relax, enjoying the nature, or an idea how to arrange the home garden. In Zen gardens there are created simple lines that do not impose any form in order to cleanse the mind of the observer for the understanding of superfluous elements, and allow the viewer to easily achieve deeper insights (Žibrat 2015).

Creating a business plan is necessary in order to cover the economic aspect. The concept of "economy" encompasses the entirety of the economic sciences, which are experienced very rapid changes due to the diversity of research. The subject of the economy is in every human activity in which we are confronted with the problem of limited resources with which to achieve the stated objectives. The task of economics is to ultimately achieve maximum efficiency, or minimisation of costs (Žnidaršič Krajnc, 1995).

By definition, investment means "increasing, or at least maintaining the value of capital”. The process of investment lies in the realization of the path from the idea or concept to the market. Property is a lever of investment, which requires a continued increase or maintaining of the value. When investing, the proceeds or output should always be higher than the input (Vuk 2001).

The aim of our study was to accurately present the plan and the company that we want to establish, and to assess the financial feasibility of the investment, which was estimated on the basis of the assessment of net present value and internal rate of return. Another important part of the study wasthe market research - the survey into the knowledge of, and interest in, Zen and Zen gardens.

\section{MATERIALS AND METHODS}

\section{Net present value and internal rate of return}

The preferred approach to the evaluation of investment projects is a dynamic method known as net present value analysis (NPV) (Pažek and Rozman 2008).

The two most important criteria for the selection of investment projects are net present value (NPV) and internal rate of return (IRR). Most often, projects are evaluated equally according to both criteria, but sometimes these two criteria offer different estimates. In theory, the concept of NPV is better, but IRR offers more results, and thereby solves the problem of the evaluation of more complex and multilayered projects. New equations of NPV contain all possible solutions for IRR as a component. The analysis confirms the theory that NPV is a better concept, but IRR remains a compulsory core part of the corresponding NPV.

The NPV estimates the effectiveness of investment in the present. NPV reduces the expected cash income from investments for the sum, which depends on three factors: the riskiness of investments, the expected inflation, and the desire of investors to get their money back upon withdrawal from the project. If the cash inflows exceed the amount of the investment, then NPV is positive, and the project is financially attractive for investors (Kierulff 2008).

The rule for an investment decision on the basis of NPV is that the investment can be taken if NPV is greater than 0 , and rejected if the NPV is less than 0 . If the NPV is equal to zero, the decision maker could decide to be indifferent. From the alternative investment options, we choose the one with the highest NPV. The investment is acceptable only in the case when there is no alternative investment, which would give higher value yields for the same cost (Čebokli 2011). For an investment of $\mathrm{t}$ periods, the formula is as follows:

$$
S F V_{i}=-1+\sum_{i=1}^{n} \frac{T R-\gamma C}{(1+r)^{i}}
$$

Where: $N P V_{t}$ - Net Present Value $(€), I$ - investment costs $(€)$, TR - total revenue $(€), \mathrm{TC}$ - total costs $(€), \mathrm{r}$ - interest rate (\%), $\mathrm{t}$ - time - number of years

The disadvantage of the NPV method is the fact that it does not take into account the value of creation of opportunities. Sometimes an investment that is inherently uneconomically feasible can create opportunities, which enable new investments for the company in favorable market conditions (Buckley 1998).

An associated concept is the IRR, which does not serve with nominal values, but rather with a discount rate, at which NPV $=0$ and represents the maximum interest rate that would be transferred to an investment in the case of financing by credit. 


\section{Landscape ecology}

Landscape ecology is a sub-discipline of ecology, which examines how patterns in space affect the spatial processes. It covers both the impact of biological processes on the landscape structure and the influence of the landscape structure on the wealth and distribution of organisms in space. The main concern of landscape ecology is the study of large-scale spatial heterogeneity, due to both natural and anthropogenic influences, and the effects of this heterogeneity on ecological processes and species persistence.

Setting a Zen garden in the woods is certainly an interference with the landscape, so the principles of landscape ecology need to be respected. Trees which absolutely have to be felled for the purpose of the garden arrangements will be used in the garden, to create simple benches, sculptures, and a variety of decorative accessories. For the purpose of the garden arrangements, it will also be necessary to fully clean the forest floor, which will destroy all undergrowth. To gain the required space, it will be necessary to remove the majority of young trees. However, it will not be necessary to discard them; they will be transplanted to the periphery, or used as an integral part of the garden. Some of the forest undergrowth plants - for example, various ferns and sedges - will be transplanted and arranged for the purpose of the systematic design of the garden.

Animals will not be driven out from the area of the garden. The assumption is that that they will eventually leave the area of their own accord, due to the noise. The area of the entire forest is much larger than that of the garden, so the animals will have the opportunity to withdraw to a quieter part of the forest.

A small market selling local produce, such as sausages, honey, pumpkin seed oil, teas, natural soaps, essential oils and so on, is planned to be in front of the garden. This will allow nearby residents to earn additional income, and, at the same time, will encourage the development of complementary activities in the region. Stands will be offered at a token rate (€2.00 per day).

\section{The impact of tourism}

Tourist activities are linked to the natural and cultural environment. An important part of Slovenian tourism is its abundant opportunities for recreation in an attractive natural environment with special and interesting elements. The expansion of different forms of recreation is increasing, due to people's desire to withdraw from urban centres and to enjoy active leisure pursuits in a healthy environment.

Increased interest in leisure activities in a natural environment brings with it a number of problems, including disturbance of the wildlife. This is known as environmental wildlife stress, and is caused by an increase in visitors and by the construction and maintenance of recreational facilities and infrastructures. Animals react to visual and auditory stimuli, as well as smells. In general, wildlife is better able to tolerate cyclical and repetitive stimuli than those which are unpredictable. For example, a motorway, which produces a constant background noise, is less disruptive to animals than a construction site which will produce sudden outbursts of noise at random times (Kolar 1999).

The development of tourism in a locality is not possible if it does not take into account the local population. It is important that local people see the value the development will add to the area. In order to gain their cooperation, local people should be integrated into the preparation of the development strategy, listened to, and, if possible, their opinions, suggestions and ideas should be taken in to account. In fact, the local population has a much greater sense of, and the best vision for, their needs for the development.

Any development of tourism cannot happen without affecting the development of the entire region. When we attract tourists with one attraction, they will visit by the way also other attractions, they will use public transport, eat in local restaurants and sleep in nearby hotels, which brings benefit to all actors and hence the entire region. However, there may cause also negative effects, such as increased traffic and thus greater noise and air pollution.

Table 1: The estimated amount of investment required to build a Zen garden

\begin{tabular}{|l|c|c|c|c|c|}
\hline & Amount & Unit & Price & Together $(€)$ \\
\hline Purchase of land & 4,000 & $\mathrm{~m}^{2}$ & 1.00 & $€ / \mathrm{m}^{2}$ & $4,000.00$ \\
\hline Paths (gravel) & 30 & $\mathrm{~m}^{3}$ & 9.00 & $€ / \mathrm{m}^{3}$ & 270.00 \\
\hline Benches & 15 & $\mathrm{pcs}$ & 80.00 & $€ / \mathrm{pcs}$ & $1,200.00$ \\
\hline Waste bins & 10 & $\mathrm{pcs}$ & 30.00 & $€ / \mathrm{pcs}$ & 300.00 \\
\hline Sand & 15 & $\mathrm{~m}^{3}$ & 17.00 & $€ / \mathrm{m}^{3}$ & 255.00 \\
\hline Rocks & 20 & $\mathrm{pcs}$ & 20.00 & $€ / \mathrm{pcs}$ & 400.00 \\
\hline Vegetation & 100 & $\mathrm{pcs}$ & 7.00 & $€ / \mathrm{pcs}$ & 700.00 \\
\hline Machine work & 50 & $\mathrm{~h}$ & 30.00 & $€ / \mathrm{h}$ & $1,500.00$ \\
\hline Handwork & 100 & $\mathrm{~h}$ & 5.66 & $€ / \mathrm{h}$ & 565.70 \\
\hline Website & 1 & $\mathrm{pcs}$ & 500.00 & $€$ & 500.00 \\
\hline Promotional material & 2,000 & $\mathrm{pcs}$ & 0.10 & $€ / \mathrm{pcs}$ & 200.00 \\
\hline Stands & 5 & & 500.00 & $€ / \mathrm{stand}$ & $2,500.00$ \\
\hline Project documentation & & & & & $1,500.00$ \\
\hline Other & & & & & $1,000.00$ \\
\hline
\end{tabular}




\section{Business plan}

A business plan is a detailed and measured description of the business or business idea. It is urgently needed if the entrepreneur wishes to obtain financial support from banks, to apply for financial aid from the various funds, or to expect cooperation from other companies. It must include real and measurable objectives, including a description of the business and branches, research and market analysis, marketing plan, financial analysis, risk assessment, and schedule. Financial projections are the most important element of any plan, and are formed after detailed analysis of the business, costs, and revenues. If the company already exists, the projections are based on results from previous years; if not, on forecasts for the future, usually for 3-5 years (Vidic 1999).

\section{Zen garden}

When designing a Zen garden, it is reasonable to bear feng shui in mind. Feng shui has been configured as a system that understands the multi-layered nature of space, together with its subtle energy levels. This is known as the school of forms, which talks about how energy flows through the landscape. The basic principle of the school of forms is that the landscape is a living being, which pervades the life energy "qi", and has the ability to regulate the flow of energy to be steady and balanced, with just the right level of intensity (Kryžanowski 2012).

In western countries, research has accumulatedon the therapeutic effects of nature since the 1970s. The gap between eastern and western countries on the topics of therapeutic landscapes and healing gardens bridges the common knowledge that green public spaces are beneficial to people's physical, mental and social health, by providing spaces for therapeutic activities and contemplation, which relieves stresses and encourages social communication (Jiang 2014).

Zen gardens seem to be an ideal place for meditation, as they are designed to defuse and concentrate thoughts. Therefore, the garden will have a lot of landscaped corners, which will offer visitors some privacy.

Zen gardening is an art form with a profound spiritual significance. Zen gardens are known as 'arid gardens' or 'stone gardens'. In their own language, the Japanese call them 'karesansui', which literally means 'water of dry mountains'.

Many Zen gardens are designed with the aim of symbolic communication of Buddhist concepts; it is possible to

Table 2: Total revenue on an annual basis

\begin{tabular}{|l|c|c|c|c|c|c|}
\hline & Price & & Amount & & Total & \\
\hline $\begin{array}{l}\text { Entrance } \\
\text { fee }\end{array}$ & 3.50 & $€$ & 6,500 & Visitors & $22,750.00$ & $€$ \\
\hline $\begin{array}{l}\text { Stands } \\
\text { rental (5) }\end{array}$ & 10 & $\begin{array}{c}€ / \\
\text { day }\end{array}$ & 262 & Days & $2,620.00$ & $€$ \\
\hline \multicolumn{7}{|l|}{ Total annual revenue } \\
\hline
\end{tabular}

Zen gardens sometimes include live plants in limited quantities, mostly moss, but always in proportion to the largely static and inanimate nature of such a garden. This is primarily a reflection of the Buddhist evaluation of the relative rarity of life and the cycle of birth and impermanence, which illustrates the change of seasons by the impact on the living nature in the garden. Many Zen gardens are positioned in such a way that each garden 'borrows' from its neighbourhood as part of its design. The purpose of such borrowing of the background is the optical zoom of the garden area and its logical connection with the surroundings. Planned gardens also fuse to the surroundings, so that they do not unduly interfere with the existing nature.

\section{RESULTS AND DISCUSSION}

\section{Investment costs}

The investment is the largest financial outlay, but it is absolutely necessary. Table 1 shows the costs and total value of the investment. The highest cost is the purchase of land, amounting to $€ 4,000.00$.

Zen garden is planned in north-eastern Slovenia in the Pomurje region, where property prices are generally lower due to a lower standard of the whole region. We have assumed the approximate average price for forest land in the market $€ 1 / \mathrm{m}^{2}$.

Part of the investment budget will be needed for machine work, buying stands, project documentation, and other aspects.

\section{Annual cash flow}

Cash flow is the movement of cash in and out during the period under analysis. This must be determined in order to 
ensure or assess the current solvency of the company. The annual cash flow (ACF) is the most important parameter when calculating the net present value. ACF was calculated as the difference between total revenue (TR) and total cost (TC). Table 2 presents the total revenues. The garden would be financed from ticket sales and the rental of stands.

The total costs, represented in Table 3, amount to $€ 19,956.60$. The biggest costs would be staff salaries. Initially, only one person will be employed at an average Slovenian salary for the month of June 2014, i.e. $€ 1,521.38$ gross. (SAOP 2014)

Other costs would be maintenance costs and advertising, which together account for $€ 1,700.00$ per year.

$\mathrm{ACF}=€ 25,370.00-€ 19,956.60$

$\mathrm{ACF}=€ 5,413.44$

\section{Break-even point of the business and break- even price of tickets}

The profitability threshold or break-even point is the moment when a company achieves a volume of business whereby it has neither a profit nor a loss. At such a volume, the company revenue sales just cover all costs. Above the breakeven price, the profit increases; below it, losses increase. A calculation of the break-even point of the volume of ticket sales, comprising the number of visitors and break-even price of tickets, is presented in Table 4.

Table 4: Break-even point in business volume

\begin{tabular}{|c|c|c|c|c|}
\hline $\begin{array}{c}\text { Nr. of } \\
\text { visitors }\end{array}$ & $\begin{array}{c}\text { Entrance } \\
\text { fee }\end{array}$ & Revenues & Expenses & Profit \\
\hline 6,500 & $€ 3.50$ & $€ 25,370.00$ & $€ 19,956.56$ & $€ 5,413.44$ \\
\hline 6,000 & $€ 3.50$ & $€ 23,620.00$ & $€ 19,956.56$ & $€ 3,663.44$ \\
\hline 5,500 & $€ 3.50$ & $€ 21,870.00$ & $€ 19,956.56$ & $€ 1,913.44$ \\
\hline 5,000 & $€ 3.50$ & $€ 20,120.00$ & $€ 19,956.56$ & $€ 163.44$ \\
\hline 4,955 & $€ 3.50$ & $€ 19,962.50$ & $€ 19,956.56$ & $€ 594$ \\
\hline 4,954 & $€ 3.50$ & $€ 19,959.00$ & $€ 19,956.56$ & $€ 2.44$ \\
\hline 4,953 & $€ 3.50$ & $€ 19,955.50$ & $€ 19,956.56$ & $€-1.06$ \\
\hline
\end{tabular}

With a planned entrance fee of $€ 3.50$, and an expected number of visitors of 6,500 , the company would have a profit of $€ 5,413.44$. By reducing the number of visitors, the profit decreases. The minimum number of visitors with which the company would still operate positively, is 4,954 ; the profit would be $€ 2.44$.

By reducing the amount of the entrance fee, profit drops sharply.

The minimum ticket price, where the company would still operate positively, under the assumption that the expected number of visitors is achieved, is $€ 2.70$ (Table 5).
Table 5: Break-even price of tickets

\begin{tabular}{|c|c|c|c|c|}
\hline $\begin{array}{c}\text { Nr. of } \\
\text { visitors }\end{array}$ & $\begin{array}{c}\text { Entrance } \\
\text { fee }\end{array}$ & Revenues & Expenses & Profit \\
\hline 6,500 & $€ 3.50$ & $€ 25,370.00$ & $€ 19,956.56$ & $€ 5,413.44$ \\
\hline 6,500 & $€ 3.30$ & $€ 24,070.00$ & $€ 19,956.56$ & $€ 4,113.44$ \\
\hline 6,500 & $€ 3.00$ & $€ 22,120.00$ & $€ 19,956.56$ & $€ 2,163.44$ \\
\hline 6,500 & $€ 2.80$ & $€ 20,820.00$ & $€ 19,956.56$ & $€ 863.44$ \\
\hline 6,500 & $€ 2.70$ & $€ 20,170.00$ & $€ 19,956.56$ & $€ 213.44$ \\
\hline 6,500 & $€ 2.60$ & $€ 19,520.00$ & $€ 19,956.56$ & $€-436.56$ \\
\hline
\end{tabular}

\section{Net present value and internal rate of return}

Evaluations of the net present value and internal rate of return are shown in Tables 6 and 7. The net present value was estimated by taking into account interest rates of $8.00 \%$. Positive business would begin in the $4^{\text {th }}$ year of operations; estimated NPV will by then be $€ 3,039.30$.

The maximum interest rate which can be managed with the investment is estimated at $16.86 \%$; estimated NPV will then be $€ 0.69$.

Table 6: Assessment of the net present value after the $5^{\text {th }}$ year of business

\begin{tabular}{|c|c|c|}
\hline Year & Interest rate $-8.00 \%$ & NPV $(€)$ \\
\hline 1 & $5,012.44$ & $-9,878.26$ \\
\hline 2 & $4,641.15$ & $-5,237.11$ \\
\hline 3 & $4,297.36$ & -939.74 \\
\hline 4 & $3,979.04$ & $3,039.30$ \\
\hline 5 & $3,684.30$ & $6,723.59$ \\
\hline
\end{tabular}

Table 7: Assessment of the internal rate of return

\begin{tabular}{|c|c|c|}
\hline Year & Interest rate $-16.86 \%$ & NPV $(€)$ \\
\hline 1 & $4,632.41$ & $-10,258.29$ \\
\hline 2 & $3,964.07$ & $-6,294.22$ \\
\hline 3 & $3,392.15$ & $-2,902.06$ \\
\hline 4 & $2,902.75$ & 0.69 \\
\hline
\end{tabular}

\section{The survey}

Among 136 respondents, there were 105 women and 31 men with an average age of 30-40 years, mostly from the countryside. Results showed that $52.2 \%$ of respondents preferred to spend their free time in natural surroundings. $36.8 \%$ of respondents were familiar with Zen and interested in the topic; $31.6 \%$ of respondents had not heard of Zen or a Zen garden, but they were interested in learning about it. $86.8 \%$ of respondents would visit a Zen garden if it was within a radius of $20-40 \mathrm{~km} .26 .5 \%$ of respondents did not mind how far away the attraction would be. $51.5 \%$ would visit a Zen garden in the springtime; $29.4 \%$ in the summer. 
$68.4 \%$ of respondents intended to visit a Zen garden out of curiosity. In terms of the entrance fee, the majority (45.4\%) were ready to pay $€ 2-3 ; 30.1 \%$ were willing to pay $€ 4-5$. $80 \%$ of respondents already had a local market nearby, but only about $30 \%$ attended it. $89.7 \%$ of respondents preferred the possibility of purchasing local products or crops when visiting local attractions (Žibrat 2014).

\section{CONCLUSIONS}

The aim of the study was to accurately present the branch and the company that we want to establish, and to assess the financial viability of the investment, which was estimated on the basis of the calculation of net present value and internal rate of return.

The survey was included for the market research reasons. It was necessary to know whether the people are interested to see the Zen garden, whether they are willing to pay an entrance fee and how much. The results of the market research were positive.

Investment in the construction of a Zen garden with corresponding activities was financially justified. The investment of $€ 14,890.70$ would be repaid in the $4^{\text {th }}$ year of operations, with a NPV of $€ 3,039.30$. In the case of financing by credit, investment may carry a $16.86 \%$ discount rate, which will encourage investors.

The investment would provide employees with a monthly income at the average Slovenian salary. As of June 2014, this was $€ 1,521.38$ gross; with the estimated visitor numbers, such a figure can be achieved. Moreover, the estimated investment clearly shows positive economic indicators; it is necessary to point out other benefits that tourism brings to the region. Development of tourism brings jobs and encourages investments in infrastructure and the preservation of natural and cultural heritage, which in turn raises the living standard of local people. Without investments, it is impossible to develop any branch. Alternatively, we may also expect impacts based solely on Zen garden, such as increasing interest in meditation, Zen, and/or yoga which is scientifically proven to have a positive impact on the quality of life of people who are engaged in this, as well as for the broader neighbourhood.

\section{REFERENCES}

1. Buckley A. International Investment Value Creation and Appraisal - A Real Options Approach. Handelshojskolens Forlag, Copenhagen Business School Press, Netherland, 1998, 272p.

2. Čebokli Z. Investicije. http://www.akc.si/investicije.php (16. june 2014).

3. Jiang S. Therapeutic landscapes and healing gardens: A review of Chinese literature in relation to the studies in western countries, Front. Architec. Res. 2014;3(2):141153.

4. Kolar B. Ekologija živali in varstvo okolja divjadi. Ljubljana, Lovska zveza Slovenije. Slovenia. 1999, 225p.

5. Kierulff H. 2008. Business Horizons - MIRR: A better measure. Bus. Horizons, 2008;51(4):321-329.
6. Kryžanowski Š. Feng shui: filozofija prostora in psihologija bivanja. Ljubljana, Mladinska knjiga. Slovenia, 2012, 352p.

7. Ministry of Economic Development and Technology. 2012. Strategy of development of Slovenian tourism (20122016). http://www.mgrt.gov.si/fileadmin/mgrt.gov. si/pageuploads/turizem/Turizem-strategije_politike/ Strategija_turizem_sprejeto_7.6.2012.pdf (23 May 2014)

8. Pažek K., Rozman Č. The real options approach for assessment of business opportunities in spelt processing. Agricultura, 2008; 6: 13-17.

9. SAOP d.o.o. http://www.saop.si/poslovne-informacije/ podatki-za-obracun-in-opomniki/povprecne-inminimalne-place/ (3 September 2014).

10. Turner M.G, Gardner R.H., O’Neill R.V. Landscape Ecology in Theory and Practice: Pattern and Process. Springer, New York. USA. 2001, 406p.

11. Turner M.G. Landscape ecology: what is the state of the science? Ann. Rev. Ecol. Evol. Syst. 2005;36:319-44.

12. Vidic F. Kako razviti uspešno podjetje. Gae College. Ljubljana, Slovenia. 1999.

13. Vuk D. Gospodarjenje s tehničnimi sredstvi 2. Investicijski management. Kranj, Moderna organizacija. Slovenia, 2001, 144p.

14. Žnidaršič Krajnc A. Ekonomika podjetja. Postojna, Slovenia. 1994.

15. Žibrat M. The survey: http://www.mojaanketa.si/ anketa/453511944/ (2014)

16. Žibrat M. Poslovni načrt za zen vrt / The business plan for a Zen garden; diplomsko delo. Maribor. 2015. 37 p: https://dk.um.si/IzpisGradiva.php?id=48000(17. september 2015). 


\section{Poslovni načrt za Zen vrt}

\section{IZVLEČEK}

Diskutirana je umestitev tematskega parka - zen vrta, kot poslovna priložnost na območju slovenskega podeželja. Natančno je predstavljena zasnova vrta z vsemi glavnimi sklopi standardnega poslovnega načrta: opis podjetja in panoge, opis storitve, analiza trga, strategija trženja, finančne projekcije ter načrt dela in aktivnosti. Finančni vidik je predstavljen z oceno finančnih parametrov kot so višina investicije, neto sedanja vrednost in interna stopnja donosa. Višina investicije projekta je ocenjena na 14.890,70 $€$, povrnila naj bi se $\mathrm{v} 4$ letih poslovanja. Ocenjena interna stopnja donosa ob povratku investicije je $16,86 \%$. Del raziskave predstavlja analiza trga -izvedba ankete o poznavanju in zanimanju za zen in zen vrt. Pri načrtovanju zen vrta so upoštevani principi krajinske ekologije, saj postavitev vrta v gozdvsekakor vpliva na krajino. 